\title{
Pelatihan dan Pendampingan Usaha di Kelompok Pengolahan dan Pemasar Hasil Perikanan (POKLAHSAR) di Dusun Lokok Rangan, Kecamatan Kayangan, Kabupaten Lombok Utara
}

\author{
Sulaimiah, Santi Nururly*, Sulhaini, Djoko Suprayetno \\ Fakultas Ekonomi dan Bisnis, Universitas Mataram, Mataram, Indonesia
}

\begin{abstract}
Article history
Received: 18 Oktober 2019

Revised: 10 November 2019

Accepted: 22 November 2019

*Corresponding Author:

Santi Nururly

Universitas Mataram, Mataram,

Indonesia;

Email: snururly@unram.ac.id
\end{abstract}

\begin{abstract}
North Lombok Regency is the most affected area due to the sequential earthquake that occurred in July 2018 on the island of Lombok. Therefore, the purpose of community service activities is to provide training and business assistance to communities that have an impact on earthquakes. The location is addressed to the Sedayu Putri Fisheries Processing and Marketers Group (POKLAHSAR) on Lokok Rangan Hamlet, Kayangan District, North Lombok Regency. The training provided on entrepreneurship and business management to produce a variety of food products from marine fish, such as shredded meat, fish bone crackers and fish bone sticks from the utilization of fish bone waste. Next to provided training on marketing and finance. The method used by lectures, consultation and assistance. Activities will be carried out from May 2019 to November 2019. The results of the activities of group members are able to produce shredded fish products, fish bone crackers and fish sticks. Expected result is the participants rose again to produce a variety of processed products from the sea acquired knowledge about the importance of packaging, used social media for broad marketing, and made financial report. Participants got back up from adversity and generated income to improve their welfare.
\end{abstract}

Keywords: management; entrepreneurship; processed; products; fish

Abtrak: Kabupaten Lombok Utara merupakan daerah yang paling berdampak akibat gempa berurutan yang terjadi pada bulan Juli 2018 di Pulau Lombok. Oleh karena itu tujuan dari kegiatan pengabdian pada masyarakat ini adalah memberikan pelatihan dan pendampingan usaha kepada masyarakat yang berdampak gempa dan salah satunya ditujukan kepada Kelompok Pengolahan dan Pemasar Hasil Perikanan (POKLAHSAR) Sedayu Putri di Dusun Lokok Rangan, Kecamatan Kayangan, Kabupaten Lombok Utara. Adapun pelatihan yang diberikan berupa pelatihan tentang kewirausahaan dan manajemen usaha untuk menghasilkan beragam produk makanan dari ikan laut, seperti abon dari dagingnya, krupuk tulang ikan serta stik tulang ikan dari hasil pemanfaatan limbah tulang ikan. Selanjutnya memberikan pelatihan tentang pemasaran dan keuangan. Metode yang digunakan dengan ceramah, konsultasi dan pendampingan. Kegiatan dilaksanakan dari bulan Mei 2019 sampai dengan bulan November 2019. Hasil yang diharapkan adalah para peserta bangkit kembali memproduksi beragam produk olahan dari laut, memperoleh pengetahuan tentang pentingnya kemasan, menggunakan media sosial untuk pemasaran yang luas, dan membuat laporan keuangan. Peserta bangkit dari keterpurukan dan menghasilkan pendapatan untuk meningkatkan kesejahteraan.

Kata Kunci: manajemen; kewirausahaan; hasil; pengolahan; ikan 


\section{PENDAHULUAN}

Kebijakan pemerintah terhadap pemberdayaan usaha mikro, kecil, dan menengah (UMKM) secara umum diarahkan untuk mendukung upaya-upaya penanggulangan kemiskinan dan kesenjangan, menciptakan kesempatan kerja, peningkatan ekspor, revitalisasi pertanian, dan pedesaan yang sesuai dengan tujuan dari Instruksi Presiden Nomor 6 Tahun 2007 yang dikuatkan oleh Undang undang No.20 tahun 2008.

UMKM sudah membuktikan di era krisis yang melanda Indonesia tahun 1998 sebagai pelaku ekonomi yang tangguh dan bertahan dalam krisis ekonomi dan era globalisasi ini. UMKM mampu menyerap tenaga kerja Berdasarkan data Kementerian Koperasi dan UKM, pada tahun 2017 tercatat lebih dari 59 juta UMKM di Indonesia, porsi UMKM sebesar 99 persen dari total usaha dan menyerap 97 persen total tenaga kerja Sementara kontribusi UMKM terhadap produk domestik bruto (PDB) sekitar 60,34 persen (Haryanti, Dewi Meisari dan Isniati Hidayah, 2017). Provinsi Nusa Tenggara Barat (NTB) terus berupaya memberikan kontribusi nyata dalam pengembangan UMKM, berdasarkan data Dinas Koperasi dan UMKM NTB, terdapat lebih dari 644 ribu unit UMKM dengan jumlah tenaga kerja yang terserap lebih dari 1,8 juta orang pada 2016 (BPS Provinsi NTB, 2017).

Namun demikian, Kinerja nyata yang dihadapi oleh sebagian besar UMKM adalah masih rendahnya produktivitas, nilai tambah, dan kualitas produk. Berdasarkan riset Bank Dunia, terdapat empat permasalahan utama yang dihadapi oleh UMKM secara nasional, yaitu aspek pembiayaan, aspek peluang usaha, kapasitas sumber daya manusia dan kelembagaan UMKM, serta regulasi dan birokrasi. Namun upaya terus dilakukan oleh pemerintah untuk mendorong UMKM sebagai agen perubahan.

Kegiatan pengabdian pada masyarakat ini dilakukan pada Kelompok Pengolahan dan Pemasar hasil perikanan (POKLAHSAR) Sedayu Putri yang ada di dusun Lokok Rangan kecamatan Kayangan Kabupaten Lombok Utara. Kelompok usaha memiliki modal Rp. 35 juta, yang dikategorikan usaha kecil menurut Undang-Undang yang mengatur tentang UMKM UU No. 20/2008. POKLAHSAR Sedayu Putri bergerak di pengolahan makanan yang mengolah hasil laut terutama dari produk ikan yang merupakan potensi daerah setempat. Kelompok ini adalah salah satu kelompok kerja yang mendapat musibah akibat dari gempa yang terjadi beberapa kali di Pulau Lombok.

Sebagaimana yang dihadapi oleh sebagian besar usaha kecil adalah rendahnya kualitas sumberdaya manusia, di bidang manajemen usaha, dan sulitnya mereka mengikuti perkembangan teknologi dewasa ini yang semakin pesat. Kendala lain yang di hadapi dalam pengembangan UMK adalah kurangnya kreativitas di dalam membuat produk yang lebih menyentuh keinginan konsumen baik dari rasa, bentuk, kemasan, dan pemasaran yang masih terbatas, dan belum bisa menjangkau daerah pemasaran yang lebih luas. Kendala- kendala tersebut juga di temukan di POKLAHSAR Sedayu Putri. Produk yang dihasilkan masih menggunakan teknologi sederhana, kemasan produk yang seadanya dan pemasaran masih terbatas untuk kebutuhan lokal, sehingga pemasaran terbatas

Kondisi ini semakin dipersulit akibat adanya gempa berturutan yang terjadi di bulan juli tahun 2018 di Lombok. Akibat dari gempa, mereka banyak kehilangan peralatan produksi yang berakibat berkurangnya jumlah produksi, akibatnya pangsa pasar yang bisa mereka masuki semakin kecil.

Upaya yang dilakukan untuk meningkatkan kemampuan kelompok maka perlu mengadakan pelatihan tentang keriwausahaan. Pendidikan atau pelatihan kewirausahaan berpengaruh positif terhadap niat berwirausaha (Anggraeni \& Nurcaya, 2016:2424; Adyana \& Purnami 2016:1160). Pelatihan pada hakikatnya adalah usaha yang terencana untuk meningkatkan keterampilan dan sikap 
yang relevan terhadap pekerjaan. Pengertian pelatihan tersebut senada dengan pendapat yang menyatakan bahwa pelatihan merupakan usaha peningkatan bakat, keterampilan, kecakapan, kemampuan dan keahlian dalam menghadapi tugas (Aditya dkk. 2015:2). Sedangkan kewirausahaan (entrepreneurship) merupakan proses menciptakan atau menambah nilai jual sesuatu dengan semangat dan perilaku yang kreatif, inovatif, serta kemampuan manajemen (Siswoyo, 2009:115). Lebih lanjut menyatakan, "Entrepreneurship adalah suatu proses kreativitas dan inovasi yang mempunyai risiko tinggi untuk menghasilkan nilai tambah bagi produk yang bermanfaat bagi masyarakat dan mendatangkan kemakmuran bagi wirausahawan". Kewirausahaan merupakan ilmu untuk mempelajari tentang nilai, kemampuan, sikap, dan perilaku seseorang dalam memenuhi tantangan hidup (Nurbudiyani, 2013:56). Dari pengertian di atas dapat disimpulkan bahwasanya pelatihan kewirausahaan merupakan usaha yang dilakukan dengan sadar dan terencana dalam meningkatkan keterampilan untuk melakukan proses kreativitas dan inovasi yang mempunyai risiko tinggi untuk menghasilkan nilai tambah suatu produk

Melihat kondisi dan permasalahan maka tim pengabdian melakukan pelatihan dan pendampingan untuk membangkitkan anggota kelompok untuk berproduksi kembali dengan materi tentang kewirausahaan (entrepreneurship) untuk membangkitkan semangat dan jiwa kewirausahaan yang tangguh dan pantang menyerah, memproduksi beragam produk dari hasil perikanan laut, pemasaran tentang kemasan yang baik, dan menarik, cara penjualan produk menggunakan internet dengan memanfaatkan sosial media untuk memperluas jangkauan pasar, serta keuangan tentang pencatatan usaha.

\section{METODE}

Kegiatan dilaksanakan dari bulan Mei 2019 sampai dengan bulan Nopember 2019. Pelaksanaan kegiatan menggunakan metode penyuluhan, konsultasi, dan pendampingan. Materi yang disampaikan dalam penyuluhan; kewirausahaan, pengembangan Sumber Daya Manusia, Pengembangan strategi pemasaran, dan pengelolaaan keuangan

\section{Solusi yang ditawarkan}

Untuk bisa membantu pengusaha dalam menyelesaikan masalahnya, maka tim pengabdian masyarakat memberikan pelatihan dan pendampingan tentang tentang kewirausahaan agar dapat menumbuhkan jiwa kewirausahaa, memberikan pengertian dan arahan tentang pengelolaan sumber daya manusia, pentingnya kemasanan dalam strategi pemasaran, dan keuangan yang meliputi pengelolaan sumber maupun penggunaan dana, pencatatan transaksi hingga penyusunan laporan keuangan.

\section{Khalayak Sasaran}

Sasaran pengabdian masyarakat ini adalah Kelompok Pengolahan dan Pemasar Hasil Perikanan (POKLAHSAR) Sedayu Putri yang ada di dusun Lokok Rangan Kecamatan Kayangan Kabupaten Lombok Utara. Sedayu Putri merupakan kelompok usaha bersama yang terdiri dari 10 pengusaha kecil yang sejenis, melakukan kegiatan produksi mengolah hasil laut berupa ikan untuk dibuat abon ikan dan krupuk ikan. Mereka melakukan penjualan secara bersama-sama. Kelompok ini merasakan dampak yang sangat besar sekali akibat dari gempa yang terjadi, rusaknya tempat mereka berproduksi, peralatan dan semangat. 
Tim pengbdian masyarakat yang berjumlah 4 (empat) orang memberikan pelatihan berupa penyuluhan atau ceramah yang berisi tentang:

1. Pengetahuan dan pendampingan kewirausahaan

2. Pengetahuan dan pendampingan pelaksanaan pengelolaan sumber daya manusia

3. Pengetahuan dan pendampingan desain kemasan

4. Pengetahuan tentang penjualan dengan menggunakan media internet melalui social media

5. Pengetahuan dan pendampingan cara menyusun laporana keuangan.

\section{HASIL DAN PEMBAHASAN}

Dari hasil penyuluhan, pengarahan dan kosultasi serta pendampingan usaha yang dilakukan oleh tim pengabdian masyarakat di dapatkan

1. Pelatihan Kewirausahaan

Kegiatan pelatihan kewirausahaan di isi dengan materi yang menjelaskan tentang ciri seorang entrepreneur (wirausahawan). Lebih lanjut dijelaskan bahwa kegiatan kewirausahaan adalah suatu proses kegiatan peningkatan pengetahuan, sikap, dan keterampilan tentang kewirausahaan yang diperuntukkan bagi masyarakat, agar mengenali, berminat dan mampu menjadi wirausahawan tangguh. Kewirausahaan pada hakekatnya adalah sifat, ciri dan watak seseorang yang memiliki kemauan dalam mewujudkan gagasan inovatif ke dalam dunia nyata secara kreatif yaitu membentuk mental dan sikap jiwa manusia yang selalu aktif untuk berusaha meningkatkan hasil karyanya dalam rangka meningkatkan pengahasilannya secara ekonomis. Suatu proses yang dilakukan oleh seseorang untuk mengejar peluang-peluang, memenuhi kebutuhan hidupnya dan mencapai keinginannya yang dijalani melalui proses inovasi (Suryana, 2000).

Kegiatan pelatihan mendorong dan memupuk jiwa pantang menyerah dan terus berjuang dalam menghadapi tanntangan-tantangan serta berusaha bangkit dari musibah gempa yang terjadi beberapa kali di kabupaten Lombok Utara yang terjadi tahun 2018. Gempa mengakibatkan rusaknya barang produksi dan keaadaan ekonomi yang sempat terhenti, menelan korban jiwa dan materi. Sehingga kegiatan pelatihan kewirausahaan ini membangkitkan kembali semangat untuk pulih dari beban jiwa karena bencana tersebut dan membenahi usaha agar bangkit kembali.
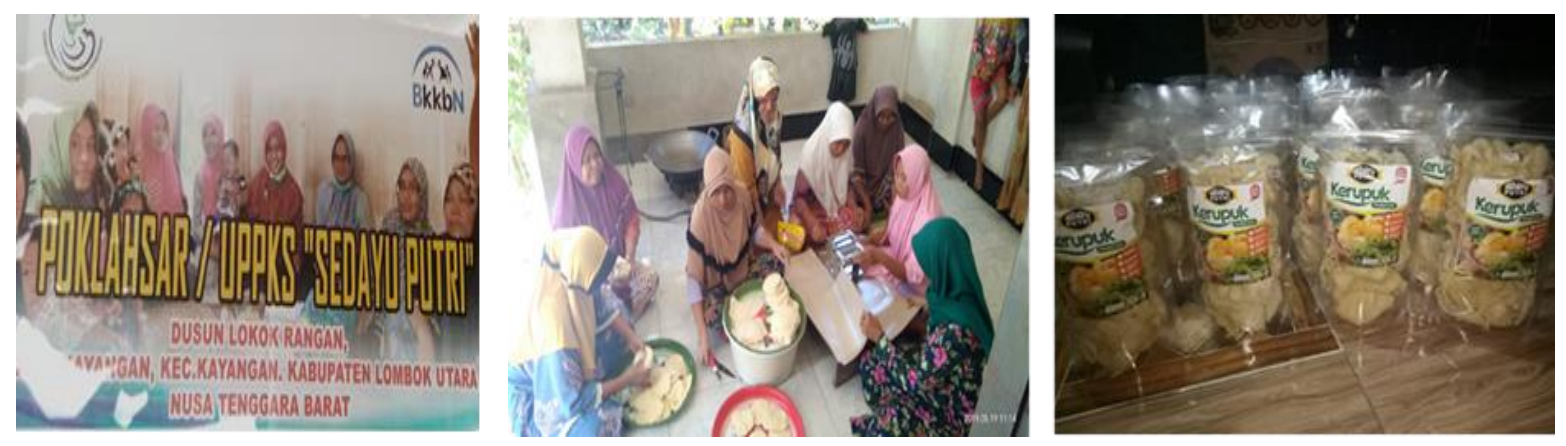

Gambar 1. Peserta menyimak Pelatihan yang diberikan (kiri); Peserta sedang berlatih membuat produk makanan olahan dari ikan (Krupuk Ikan) (tengah); dan Kemasan Produk yang dihasilkan (kanan)

2. Pelatihan Pengembangan Sumber Daya Manusia

Pelatihan diisi dengan ceramah dan diskusi tentang pentingnya peranan para peserta sebagai sumber daya manusia yang berpotensi. Mereka sebagai penggerak dari usaha tidak boleh berhenti walau 
ditimpa oleh musibah. Sebagaimana diketahui daerah mereka termasuk salah satu daerah yang terkena bencana gempa di Lombok. Kegiatan pengabdian ini dimaksudkan untuk membangkitkan mereka kembali untuk kembali berusaha.

Kegiatan diisi dengan memberikan bantuan peralatan dan bersama dengan tim pengabdian mengajak mereka kembali untuk mengolah produk yang menjadi potensi andalan daerah Lombok Utara yaitu hasil dari laut berupa ikan laut. Produk ikan diolah sehingga menghasilkan beragam produk olahan makanan seperti abon dan krupuk ikan dari dagingnya, krupuk tulang ikan serta stik tulang ikan dari hasil pemanfaatan limbah tulang ikan.

Kegiatan pelatihan membangkitkan para peserta kembali untuk menyadari bahwa mereka harus terus berproduksi. Pelatihan juga memberikan pengetahuan tentang perlunya memperhatikan kualitas produk yang dihasilkan sehingga pengolahan hasil laut yang dihasilkan memiliki kualiatas yang bisa bersaing dengan UMKM sekitar atau lokal, serta ke depan mampu menembus pangsa pasar di luar daerah.

Pelatihan yang diadakan mendapat respon yang positif dari peserta yang ditunjukkan dengan antusia peserta yang mengikuti pelatihan. Mereka memproduksi kembali dan bangkit kembali untuk menghasilkan produk-produk dari olahan laut.

\section{Pelatihan Pemasaran dengan membuat kemasanan yang menarik}

Peserta diberikan pelatihan tentang membuat kemasan (packaging). Pelatihan berisi penjelasan tentang manfaat kemasan sebagai wadah atau sarana pembungkus produk yang mempunyai fungsi ganda, yaitu dapat membantu mencegah atau mengurangi kerusakan disaat distribusi barang, serta sangat berperan dalam menentukan keputusan konsumen untuk melihat atau bahkan membeli produk tersebut. Penjelasan lebih lanjut kepada peserta bahwa riset di Amerika, Indonesia, Jepang dan negara lainnya telah membuktikan bahwa kemasan unik dan menarik dapat mendongkrak penjualan produk.

Peserta juga diberikan pengetahuan tentang fungsi utama kemasan yaitu untuk menempatkan produk hasil pengolahan sehingga proses angkut, simpan, dan kirim produk mudah dilakukan sekaligus menghemat tempat. Walaupun demikan, ada pula yang mengesampingkan fungsi hemat tempat ini, alasan utamanya adalah untuk menonjolkan identitas atau lebih keren dikenal dengan sebutan brand sekaligus menarik pembeli yang menyukai bentuk kemasan unik dan artistik.

Ada tiga alasan utama mengapa desain kemasan penting dalam pemasaran:

1. Desain kemasan dapat membentuk pola loyalitas konsumen dengan cara mempengaruhi psikologis dan emosional. Contohnya melalui warna, keunikan bentuk kemasan, ilustrasi dan layout.

2. Desain kemasan sangat berpengaruh terhadap standar perusahaan dalam penetapan harga sebuah produk diluar produksi.

3. Desain kemasan membuat sebuah produk mempunyai identitas yang membuatnya berbeda diantara produk lainnya sejalan dengan persaingan merk dagang yang semakin kompetitif.

Peserta hadir dan antusias dalam mengikuti pelatihan yang diberikan. Selanjutnya dalam kegiatan pelatihan, peserta langsung diberikan contoh bentuk kemasan dengan desain yang menarik dan berisi informasi tentang produk yang dijual. Sehingga mereka dapat mempraktekkan langsung desain yang baik dan menarik. Gambar 4 menunjukkan kemasan produk yang dihasilkan. 
4. Penjualan menggunakan media internet.

Pelatihan penjualan dengan menggunakan media internet, yang diberikan pada kegiatan pelatihan diisi dengan ceramah dan tanya jawab tentang perkembangan teknologi informasi sangat pesat. Salah satu contohnya adalah perkembangan telepon seluler dan internet, keberadaannya memberikan pengaruh bagi berbagai aspek kehidupan, baik kehidupan secara individu, sosial maupun yang terkait dengan dunia usaha atau bisnis. Lebih lanjut dijelaskan bahwa sosial media menjadi tempat pemasaran yang efektif karena beberapa hal, antara lain:

a. Saat ini sarana internet manfaatnya bisa dinikmati oleh berbagai kalangan masyarakat; termasuk menggunakannya untuk 'bermain' di jejaring sosial

b. Banyaknya media sosial yang dapat diakses dengan sangat mudah; bahkan satu orang bisa menjadi anggota dari banyak sosmed

c. Mudahnya prosedur penyebaran informasi di sosial media; pebisnis hanya perlu membuat artikel, tulisan, gambar, video, atau bentuk informasi lainnya dan menaruhnya di media sosial tertentu

d. Adanya pemberitahuan atau notifikasi kepada pengguna media sosial, termasuk ketika ada postingan baru dari pebisnis tertentu; sehingga informasi bisa diketahui dengan cepat

e. Jangkauan yang luas; artinya, satu pesan yang sama bisa langsung tersampaikan ke banyak orang

f. Media Sosial untuk Bisnis Online dan Offline

Penggunaan internet sebagai sarana utamanya, dimana peran media sosial tidak terbatas pada meningkatkan pendapatan atau penjualan bisnis-bisnis online, namun bisnis offline pun dapat memanfaatkan berbagai situs jejaring sosial untuk menyokong pemasaran produknya. Tidak sulit untuk mempromosikan produk baru, program diskon, serta informasi lain dari pemilik bisnis offline agar pengguna media sosial tertarik untuk 'melirik' dan membeli produknya. Cukup dengan membuat artikel, video, dan sebagainya; untuk kemudian diunggah melalui akun yang dimilikinya. Kemudahan inilah yang membuat fungsi media sosial begitu lekat dengan upaya peningkatan penjualan baik bisnis online, maupun offline.

Dalam kegiatan pelatihan penjualan menggunakan internet baru menggunakan WhatsApp, karena kemampuankcomputer dari peserta masih terbatas, sehingga kedepan kegiatan pengabdian pada masyarakat bisa dilanjutkan.

\section{Pelatihan Keuangan}

Pelatihan keuangan berisi pembelajaran tentang proses pencatatan transaksi keuangan yang terjadi setiap harinya. Pencatatan dilakukan untuk mencatat biaya apa saya yang masuk dan keluar di dalam perusahaan. Penekanannya pencatatan yang baik akan mempengaruhi keberhasilan dalam usaha yang dijalankan.

Lebih lanjut dijelaskan bahwa poses pencatatan harus dilakukan secara teratur, dikumpulkan dan dipilah menurut kategori harta, kewajiban, modal, penghasilan dan biaya. Dari sana tercatat jumlah harga perolehan dan penyerahan barang yang diberikan. Proses ini kemudian ditutup dengan menyusun laporan keuangan untuk satu periode tertentu (Riyanto, 2004). Selain itu dijelaskan bahwa dari laporan keuangan didapatkan informasi tentang kondisi keuangan, kinerja usaha, dan kondisi keuangan usaha yang dapat diambil manfaatnya oleh pengusaha untuk pengambilan keputusan kemudian hari. 
Pada kegiatan pelatihan diberikan pemahaman bahwa pencatatan keuangan usaha harus dipisahkan dengan harta sendiri. Sehingga laporan keuangan yang dihasilkan akan memisahkan asset pribadi dengan asset usaha, sehingga meminimalkan resiko usaha ke dalam kehidupan pribadi, dan membuat menjadi professional. Antusias para peserta terhadap pelatihan ini sangat baik, ditunjukkan dengan mereka langsung membuat laporan keuangan dengan dibantu dan didampingi oleh tim pengabdian.

\section{KESIMPULAN DAN SARAN}

\section{Kesimpulan}

Kegiatan Pengabdian masyaarakat ini dapat berjalan dengan baik dan memberikan manfaat bagi Kelompok Pengolahan dan Pemasar Hasil Perikanan (POKLAHSAR) Sedayu Putri di Dusun Lokok Rangan, Kecamatan Kayangan, Kabupaten Lombok Utara. Para peserta antusias dan memberikan respon yang positif. Kegiatan pelatihan membuat peserta memproduksi beragam produk olahan makanan dari hasil perikanan laut seperti abon dan krupuk ikan dari dagingnya, krupuk tulang ikan serta stik tulang ikan dari hasil pemanfaatan limbah tulang ikan yang dikemas dengan menarik dan cantic. Peserta memperoleh pengetahuan tentang kewirauasahaan, pengelolaan sumber daya manusia, membuat kemasan yang menarik, menggunakan media sosial untuk pemasaran yang luas, dan membuat laporan keuangan. Gempa yang menggucang daerah mereka dan merusak usaha yang membuat mereka jatuh, dibangkitkan kembali, sehingga peserta kembali berusaha dan menghasilkan pendapatan untuk meningkatkan kesejahteraan.

\section{Saran}

Kegiatan pengabdian pada masyarakat kedepannya, lokasi ini bisa dijadikan prioritas untuk kegiatan dengan memberikan materi tentang pemanfaatan teknologi digital, untuk memperluas pemasaaran.

\section{Ucapan Terima Kasih}

Terima kasih penulis sampaikan kepada Lembaga Penelitian Universitas Mataram yang telah mendanai kegiatan pengabdian kepada masyarakat melalui dana DIPA BLU (PNBP) Fakultas Ekonomi dan Bisnis Universitas Mataram Tahun Anggaran 2019

\section{DAFTAR PUSTAKA}

Aditya, R., Utami, H.N., \& Ruhana, I. 2015. Pengaruh Pelatihan terhadap Kompetensi dan Kinerja Karyawan (Studi pada Karyawan PT. PLN (Persero) Distribusi Jawa Timur Area Malang). Jurnal Administrasi Bisnis, (Online), 2(27): 1-6 http://administrasibisnis. Studentjournal.ub.ac.id/ index.php/ jab/article/ view/1097/1280)

Adyana, G.L.A., \& Purnami, N.M. 2016. Pengaruh Pendidikan Kewirausahaan, Self Efficacy, dan Locus of Control pada Niat Berwirausaha. Jurnal Manajemen, (Online), 2 (5):1160-1188: https://media.neliti.com/media/publications/253915

Anggraeni, D.A.L., \& Nurcaya, I.N. 2016. Peran Efikasi Diri dalam Memediasi Pengaruh Pendidikan Kewirausahaan terhadap Niat Berwirausaha. Jurnal Manajemen, (Online), 4(5):2424-2453 http://media.neliti.com/media/publications/241653-peran-efikasi-diridalam-memediasi-pengace105b1.pdf 
BPS Provinsi NTB. 2017. Potensi Ekonomi Provinsi Nusa Tenggara Barat. Sensus Ekonomi 2016. Anaisis Hasil Listing. https://ntb.bps.go.id. Diakses tg 05 September 2019

Haryanti, Dewi Meisari dan Isniati Hidayah. 2017. Potret UMKM Indonesia: Si Kecil yang Berperan Besar. https://www.ukmindonesia.id/baca-artikel/62. Diaksses 05 September 2019

Nurbudiyani, I. 2013. Model Pembelajaran Kewirausahaan dengan Media Koperasi Sekolah di SMK Kelompok Bisnis dan Manajemen. Jurnal Pendidikan Vokasi, (Online), 1(3):53-67 https://journal. uny.ac.id/ index.php/jpv/article/view/1577/1303

Siswoyo, B.B. 2009. Pengembangan Jiwa Kewirausahaan Dikalangan Dosen dan Mahasiswa. Jurnal Ekonomi Bisnis, (Online), 2(2009):114-123 http://fe.um.ac.id/wp-content/uploads/ 2009/10/ bambang_banu4.pdf

Riyanto, Bambang. 2004. Dasar-dasar Pembelanjaan Perusahaan, Ed. 4. BPFE UGM, Yogyakarta Suryana. 2009. Kewirausahaan. Jakarta: Salemba Empat Undang undang No.20 tahun 2008. 